\title{
Adhesion and invasion of Streptococcus pneumoniae to primary and secondary respiratory epithelial cells
}

\author{
SARA NOVICK ${ }^{1,2^{*}}$, MARILOUS SHAGAN ${ }^{1,2^{*}}$, KARIN BLAU $^{1,2}$, SARIT LIFSHITZ $^{1,2}$, \\ NOGA GIVON-LAVI ${ }^{2}$, NILI GROSSMAN ${ }^{1 \#}$, LIPA BODNER $^{3}$, RON DAGAN $^{4}$ and YAFFA MIZRACHI NEBENZAHL ${ }^{1,2}$ \\ ${ }^{1}$ Shraga Segal Department of Microbiology and Immunology; ${ }^{2}$ Pediatric Infectious Disease Unit, \\ Soroka University Medical Center, Faculty of Health Sciences, Ben-Gurion University of The Negev, \\ Beer Sheva 84101; ${ }^{3}$ Oral and Maxillofacial Surgery Unit, Soroka University Medical Center, Beer Sheva 84105; \\ ${ }^{4}$ Faculty of Health Sciences, Ben-Gurion University of The Negev, Beer Sheva 84101, Israel
}

Received June 14, 2016; Accepted September 30, 2016

DOI: $10.3892 / \mathrm{mmr} .2016 .5996$

\begin{abstract}
The interaction between Streptococcus pneumoniae (S. pneumoniae) and the mucosal epithelial cells of its host is a prerequisite for pneumococcal disease development, yet the specificity of this interaction between different respiratory cells is not fully understood. In the present study, three areas were examined: i) The capability of the encapsulated $S$. pneumoniae serotype 3 strain (WU2) to adhere to and invade primary nasal-derived epithelial cells in comparison to primary oral-derived epithelial cells, A549 adenocarcinoma cells and BEAS-2B viral transformed bronchial cells; ii) the capability of the unencapsulated 3.8DW strain (a WU2 derivative) to adhere to and invade the same cells over time; and iii) the ability of various genetically-unrelated encapsulated and unencapsulated $S$. pneumoniae strains to adhere to and invade A549 lung epithelial cells. The results of the present study demonstrated that the encapsulated WU2 strain adhesion to and invasion of primary nasal epithelial cells was greatest, followed by BEAS-2B, A549 and primary oral epithelial cells. By contrast, the unencapsulated 3.8-DW strain invaded oral epithelial cells significantly more efficiently when compared to the nasal epithelial cells. In addition, unencapsulated S. pneumoniae strains adhered to and invaded the A459 cells significantly more efficiently than the encapsulated strains; this is consistent with previously published data. In conclusion,
\end{abstract}

Correspondence to: Professor Yaffa Mizrachi Nebenzahl, Pediatric Infectious Disease Unit, Soroka University Medical Center, Faculty of Health Sciences, Ben-Gurion University of The Negev, PO Box 151, Ben-Gurion Avenue, Beer-Sheva 84101, Israel E-mail: ymizr@bgu.ac.il

*Contributed equally

${ }^{\#}$ Deceased

Key words: Streptococcus pneumoniae, adhesion, invasion, primary nasal epithelial cells, primary oral epithelial cells, viral transformed bronchial cells, lung carcinoma-derived cells the findings presented in the current study indicated that the adhesion and invasion of the WU2 strain to primary nasal epithelial cells was more efficient compared with the other cultured respiratory epithelial cells tested, which corresponds to the natural course of $S$. pneumoniae infection and disease development. The target cell preference of unencapsulated strains was different from that of the encapsulated strains, which may be due to the exposure of cell wall proteins.

\section{Introduction}

Streptococcus pneumoniae (S. pneumoniae) is part of the commensal flora of the human respiratory tract, however, virulent strains of $S$. pneumoniae $(1,2)$ or co-infection with other microbes (3), may transform this commensal bacterium into a pathogen. Pathogenic $S$. pneumoniae can spread to sterile mucosal surfaces and cause otitis media and pneumonia, or may lead to sepsis or meningitis through invasion of the host (4). Despite the currently available antibiotic treatments and vaccines for $S$. pneumoniae infections, the annual worldwide morbidity in children under five years of age reached approximately one million children, whilst mortality reached around 200,000 children (5). These rates clearly highlight the requirement for the development of alternative therapeutic approaches and reliable assays for determining treatment effectiveness.

Antibiotic treatments against $S$. pneumoniae are currently less effective than they were three decades ago, as a result of the persistent emergence of antibiotic-resistant strains $(6,7)$. Anti-S. pneumoniae vaccines in current use, are based on the capsular polysaccharides of the bacterium. An example of this includes the Pneumovax vaccine, which has exhibited $60 \%$ effectiveness in preventing invasive pneumococcal diseases in the elderly (8). The incomplete coverage occurs as a result of incomplete coverage against all 97 currently known serotypes or a poor immune response against certain serotypes included in the vaccine, including serotype 3 . However, Pneumovax does not elicit long-term immune memory or protective immune responses in infants $<2$ years of age (8). To overcome this caveat, pneumococcal capsular polysaccharides have been conjugated to various carrier proteins to produce conjugate 
vaccines. These currently include between 10 and 15 serotypes $(9,10)$. However, to date, 98 S. pneumoniae serotypes have been identified $(11,12)$, and pneumococcal carriage and disease caused by serotypes that are not included in the conjugate vaccines are constantly emerging $(13,14)$. This further emphasizes the need for new therapeutic approaches and improved vaccines. The development of new preventative and therapeutic interventions is hampered due to an incomplete understanding of pneumococcal pathogenesis.

$S$. pneumoniae colonizes the nasopharynx by adhering to mucosal cells of the upper respiratory tract, which is a prerequisite for disease development (15). Therefore, the nature of $S$. pneumoniae adhesins has been investigated over the past two decades $(16,17)$. Among the molecules known to initiate the $S$. pneumoniae-host interaction that leads to nasopharyngeal colonization, include two types of pili. The type I pilus is an oligomeric appendage, which is encoded by the $r l r A$ operon $(18,19)$. Its adhesin, the RrgA protein, binds to the toll-like receptor (TLR) 2 (20). The type II pilus is encoded by a pathogenicity islet (PI)-II (21). Following the initial attachment to mucosal cells, the bacteria partially shed their polysaccharide capsule at the site of adhesion to provide access to the respiratory mucosa and facilitate the exposure of adhesive molecules embedded within the bacterial cell wall or cytoplasmic membrane (22). Among the adhesins present on the $S$. pneumoniae membrane and cell wall are the proteins; the lipoprotein PsaA (23), which binds to the E-cadherin receptor (24), and the PavA protein (25), which binds to the extracellular matrix (ECM) protein fibronectin and to the cell adhesion molecule integrin. Other adhesins include fructose bisphosphate aldolase, which binds to the flamingo cadherin receptor (26), NADH oxidase, which binds to the ECM protein laminin $\alpha 5$ (among other putative receptors) (27), and phosphoenolpyruvate protein phosphotransferase, which binds to the BMP binding endothelial regulator and Eps 1 proteins, among other putative receptors (28).

After attachment of the bacteria to the mucosal cells of the host has been established, S. pneumoniae may invade the cells either by binding phosphorylcholine or choline-binding protein A (CbpA), also known as SpsA or PspC to the platelet-activating factor receptor (PAF-R) (29), which is present in epithelial and endothelial cells (30-32). This binding may initiate the PAF-R recycling pathway, which transports bacteria to the basal membrane of the host and leads to the development of an invasive disease. In addition, the pneumococcal $\mathrm{CbpA}$ may bind to the polymeric immunoglobulin receptor ( $\mathrm{pIgR})$ or to secretory IgA (33-35). Following attachment to the pIgR, the pneumococci exploit the recycling pathway to traverse the epithelium from the apical to the basement membrane. Notably, many adhesins and invasins, including, PspA, CbpA, PavA, PavB and $\mathrm{PhtD}$, are known to be immunogenic and elicit a protective immune response in mouse model systems (36-39).

In the search for effective therapeutic targets, tissue cultures of cancer-derived or immortalized cell lines are most often used to identify new molecules that may be involved in bacterial virulence (22-29). In the current study, these tissue cultures were examined to investigate whether they are appropriate models for studying the interactions between $S$. pneumoniae and its host. In addition, although a significant amount of information has been gathered regarding the interaction between $S$. pneumoniae and its host cells (22-29), the extent and specificity of the interaction with primary upper respiratory cells and secondary lower respiratory cells has not been fully described. Thus, the present study compared the abilities of $S$. pneumoniae to adhere to and invade nasal-derived epithelial cells (nasal cells), oral-derived epithelial cells (oral cells) from primary cell lines, as well as bronchial-virus transformed cells (BEAS-2B) and type II adenocarcinoma derived epithelial (A549) cells.

The present study investigated the interaction between non-encapsulated pneumococcal strains and the respiratory tissue derived epithelial cells, as they have been recently demonstrated to be involved in $S$. pneumoniae diseases to a larger extent than previously assumed (40). Non-encapsulated $S$. pneumoniae are subdivided into the following two groups: Group I, which possess a mutation or deletion in the cps locus, thereby preventing capsular synthesis; and group II, where the cps locus is replaced by a gene or genes that code for proteins, such as two aliB homologues (aliC and aliD), which are peptide-binding molecules associated with an ATP-binding cassette transporter $(41,42)$ or $p s p K(40)$. $p s p K$ encodes a protein with a long alpha-helical region containing an LPxTG motif and a YPT motif known to bind human pIgR (43), necessary for nasopharyngeal carriage in mice.

Respiratory epithelial cells derived from cancers of the respiratory system and virus immortalized cells are widely used as in vitro models for $S$. pneumoniae infections (22-29). However, the validity of these cell lines to reproduce the functions of primary respiratory cells remains to be fully determined. The present study aimed to compare the $S$. pneumoniae adhesion to and invasion of primary respiratory cells with their interaction with the cancer-derived cell lines and virus-immortalized cells. The results of the present study suggest that the adhesion and invasion to the different types of cells is concomitant with the natural course of infection and disease development. In addition, the exposure of surface proteins, which occurs in unencapsulated strains, alters the target cell preferences of $S$. pneumoniae. The epithelial cell cultures described in the current study may be used as a platform for the future identification of molecules that define the specificity of $S$. pneumoniae infection and its affinity to various tissues.

\section{Materials and methods}

Reagents. All chemicals and biochemical reagents were of the highest purity available and, unless otherwise stated, were purchased from Sigma-Aldrich; Merck Millipore (Darmstadt, Germany).

Bacterial strains. The bacterial strains used in the current study included the encapsulated $S$. pneumoniae serotype 3 WU2 strain and its unencapsulated variant 3.8-DW (kindly provided by Professor David Watson, University of Texas, Galveston, TX, USA) (44), the encapsulated serotype 2 strain D39-LM (provided by Professor Larry S. McDaniel, University of Mississippi Medical Center, Jackson, MS, USA) and its unencapsulated variant R6 [American Type Cell Collection (ATCC)] (45). The encapsulated strains 23F-RD (serotype 23F) and 6B-RD (serotype 6B) were clinical strains obtained from 
the collection of the Pediatric Infectious Disease Unit (Soroka University Medical Center, Beer-Sheva, Israel). S. pneumoniae were plated onto tryptic soy agar supplemented with $5 \%$ sheep erythrocytes (Biological Industries, Beit Haemek, Israel) and incubated for $17-18 \mathrm{~h}$ at $37^{\circ} \mathrm{C}$ under anaerobic conditions. The bacteria were then transferred to a Todd-Hewitt broth supplemented with $0.5 \%$ yeast extract (THY), incubated at $37^{\circ} \mathrm{C}$ until mid-logarithmic phase (as determined by a growth curve), and isolates were harvested when the optical density (OD) was equal to $\sim 0.55$ at absorbance $(\mathrm{A})_{620}$. The colony-forming unit (CFU) content of the preparations was verified in each experiment by using agar plates supplemented with 5\% sheep erythrocytes (Biological Industries).

Cell culture. Mucosal epithelial cells were isolated from discarded segments of healthy oral or nasal mucosa, using the method described by Ueda et al (46) with minor modifications. These segments were provided by Professor Lipa Bodner (Oral and Maxillofacial Surgery Unit, Soroka University Medical Center) and obtained from one patient who underwent oral surgery and one patient that underwent nasal surgery. The samples were obtained from healthy areas in the oral and nasal cavities. All human studies, protocol revisions, and consent procedures were approved by the Helsinki Ethics Committee of the Soroka University Medical Center (permit no. 4995). Written informed consent was obtained from each individual.

Ten mucosal segments (5 $\mathrm{mm}$ in diameter) were immersed for $30 \mathrm{~min}$ in a phosphate-buffered saline (PBS) solution containing penicillin $(100 \mathrm{U} / \mathrm{ml})$, streptomycin (100 $\mu \mathrm{g} / \mathrm{ml})$, gentamycin $(50 \mu \mathrm{g} / \mathrm{ml})$, amphotericin $\mathrm{B}$ $(2.5 \mu \mathrm{g} / \mathrm{ml})$ and neomycin $(0.4 \%)$. The mucosal segments were then incubated for $16 \mathrm{~h}$ at $4^{\circ} \mathrm{C}$ in Dulbecco's Modified Eagle's Medium (DMEM) containing the aforementioned antibiotics, along with dispase $(2 \mathrm{U} / \mathrm{ml}$; Roche Diagnostics $\mathrm{GmbH}$, Mannheim, Germany). The epidermis was peeled off and incubated in $0.25 \%$ trypsin with antibiotics (aforementioned mixture of penicillin, streptomycin, gentamycin, amphotericin and neomycin) at $37^{\circ} \mathrm{C}$ for $60 \mathrm{~min}$, before being transferred to a $10 \mathrm{ml}$ volume of keratinocyte seeding medium, according to the procedures described by Rheinwald and Green (47). The keratinocyte seeding medium contained DMEM: F12 (3:1), fetal calf serum (FCS; 10\%), glutamine (2 mM), penicillin $(100 \mathrm{U} / \mathrm{ml})$, streptomycin $(100 \mu \mathrm{g} / \mathrm{ml})$, gentamycin (50 $\mu \mathrm{g} / \mathrm{ml})$, amphotericin B $(2.5 \mu \mathrm{g} / \mathrm{ml})$, adenine $(0.18 \mathrm{mM})$, hydrocortisone $(0.4 \mu \mathrm{g} / \mathrm{ml})$, insulin $(5 \mu \mathrm{g} / \mathrm{ml})$, transferrin $(5 \mu \mathrm{g} / \mathrm{ml})$ and tri-iodothyronine $(2 \mathrm{nM})$. In addition to the above, the keratinocyte growth medium contained cholera toxin $(0.1 \mathrm{nM})$ and epidermal growth factor (EGF; $5 \mathrm{ng} / \mathrm{ml})$. A single-cell suspension, obtained following a 2-min vortex, was then plated on a mitomycin $\mathrm{C}$-treated feeder layer of $3 \mathrm{~T} 3$ cells (ATCC) in 35-mm diameter tissue culture plates (Corning Inc., Corning, NY, USA) at a seeding density of 20,000 cells $/ \mathrm{cm}^{2}$. Cultures were incubated in an environment of $37^{\circ} \mathrm{C}, 8 \% \mathrm{CO}_{2}$ and $95 \%$ humidity, and the keratinocyte growth medium was replenished every other day. Keratinocytes were routinely sub-cultured onto fresh feeder cells after reaching $80 \%$ confluence, following the selective removal of the feeders with EDTA $(0.02 \%$ in PBS) and trypsinization (48). Experiments were performed with nasal and oral mucosal cells at passage four or five. At this point, cells $\left(2.5 \times 10^{4} /\right.$ well $)$ were seeded in 96 -well plates (Corning Inc.) with a keratinocyte seeding medium in the absence of feeder cells. The cells were incubated for $24 \mathrm{~h}$ without antibiotics prior to conducting the adhesion assay, at which time they had reached a density of $\sim 5 \times 10^{4}$ cells/well.

The virus-transformed bronchialBEAS-2B cell line(ATCC) was cultured in an LHC-9 medium (Biological Industries) containing $0.5 \mathrm{ng} / \mathrm{ml}$ recombinant EGF, $500 \mathrm{ng} / \mathrm{ml}$ hydrocortisone, $0.005 \mathrm{mg} / \mathrm{ml}$ insulin, $0.035 \mathrm{mg} / \mathrm{ml}$ bovine pituitary extract, $500 \mathrm{nM}$ ethanolamine, $500 \mathrm{nM}$ phosphoethanolamine, $0.01 \mathrm{mg} / \mathrm{ml}$ transferrin, $6.5 \mathrm{ng} / \mathrm{ml} \mathrm{3,3',5-triiodothyronine,}$ $500 \mathrm{ng} / \mathrm{ml}$ epinephrine, $0.1 \mathrm{ng} / \mathrm{ml}$ retinoic acid.

The A549 lung adenocarcinoma cell line (ATCC) was used as it retains the morphological, biochemical, and immunological characteristics of type II lung epithelial cells (49-52). The cells were cultured in DMEM (Biological Industries) supplemented with 10\% FCS (Biological Industries), penicillin and streptomycin (100 $\mu \mathrm{g} / \mathrm{ml}$ each). At $24 \mathrm{~h}$ prior to experiments, the cells were transferred to 96-well plates without antibiotics, and the cultures were then blocked with DMEM supplemented with $0.5 \%$ gelatin and incubated for $4 \mathrm{~h}$ at $37^{\circ} \mathrm{C}$. The cell count was, on average, 50,000 cells/well.

Cell adhesion assay. S. pneumoniae from fresh overnight blood agar cultures were inoculated into the THY broth and cultivated at $37^{\circ} \mathrm{C}$ until they reached mid-logarithmic phase $\left(\mathrm{A}_{620}, \mathrm{OD}=\sim 0.55\right)$. The bacteria were diluted in PBS to a final concentration of $2 \times 10^{7} \mathrm{CFU} / \mathrm{ml}$. A total of $200 \mu \mathrm{l}$ diluted bacteria $\left(\sim 4 \times 10^{6} \mathrm{CFU} / 200 \mu \mathrm{l}\right)$ was added to the $5 \times 10^{4}$ cultured cells/well (multiplicity of infection $~ 80: 1$ ). Bacteria and cells were incubated for $15,30,60$ or $90 \mathrm{~min}$ at $37^{\circ} \mathrm{C}$. These time points were selected as preliminary experiments revealed no alteration in the survival of the cells in the presence of bacteria during this time period. As a negative control, the same volume of PBS containing the bacteria was added to wells that did not contain mammalian cells. At each of the denoted time points, the wells were extensively washed with PBS five times, and the cells were removed from the wells by incubating the culture with $0.25 \%$ trypsin and $0.02 \%$ EDTA for $5 \mathrm{~min}$. Cultured cells were counted at the end of the experiment and the cell number did not differ significantly from their number prior to the addition of the bacteria. The suspension was serially diluted and plated on $5 \%$ sheep blood agar plates, before they were incubated at $37^{\circ} \mathrm{C}$ under anaerobic conditions for $17-18 \mathrm{~h}$ for CFU determination. For each experiment, 4-6 replicates were performed at least three times. Representative experiments are presented in the figures.

Cell invasion assay. All of the initial steps were the same as those used in the adhesion assay, except that penicillin $(100 \mu \mathrm{g} / \mathrm{ml})$ and gentamicin $(50 \mu \mathrm{g} / \mathrm{ml})$ were added to the culture media for $45 \mathrm{~min}$ at the same aforementioned time points. The antibiotics in the supernatant were removed and the cells were removed from the wells by using $0.25 \%$ trypsin and $0.02 \%$ EDTA for $5 \mathrm{~min}$. The cells were then lysed using $0.02 \%$ saponin, and the suspension was serially-diluted and plated on sheep blood agar plates, which were then incubated under anaerobic conditions for $17-18 \mathrm{~h}$ for CFU determination. For each experiment, six replicates were performed at least three times. 
Statistical analyses. The present study used non-parametric Pearson analysis to determine alterations in adhesion efficiency over time (at 15, 30, 60, 90 and 120 min of incubation). One-way analysis of variance was employed to compare the adhesion and invasion curves of the different epithelial cells. For multiple comparisons at all time points the Tukey post-hoc test was used. Statistical analyses were performed in GraphPad Prism software version 7 (GraphPad Software, Inc., La Jolla, CA, USA). $\mathrm{P}<0.05$ was considered to indicate a statistically significant difference.

\section{Results}

Adhesion of S. pneumoniae serotype 3 strain WU2 and the unencapsulated derivative 3.8 strain to primary and secondary respiratory epithelial cells. The adhesion of the WU2 strain to the epithelial cells increased in a time-dependent manner in all cell types tested (Fig. 1A; nasal cells, $r=0.9995, P=0.0005$; oral cells, $\mathrm{r}=0.9461, \mathrm{P}=0.0149 ; \mathrm{A} 549$ cells, $\mathrm{r}=0.948, \mathrm{P}<0.02$; BEAS-2B cells, $r=0.9707, \mathrm{P}=0.006$ ). However, analysis of all curves (Fig. 1A) revealed that WU2 adhesion was significantly more efficient to nasal cells compared with BEAS-2B cells $(\mathrm{P}=0.0193)$, A549 cells $(\mathrm{P}=0.0003)$ and oral cells $(\mathrm{P}=0.0001)$. Analysis performed at each time point revealed significantly greater efficiency of WU2 adhesion to nasal cells than to any of the other types of epithelial cell assessed (nasal vs. A549, $\mathrm{P}=0.0003$; nasal vs. oral, $\mathrm{P}=0.0001$; nasal vs. BEAS-2B, $\mathrm{P}=0.0193$ ). The adhesion of WU2 to BEAS-2B cells was significantly more efficient than to A549 cells at the 90 and 120 min time points $(\mathrm{P}=0.0024$ and $\mathrm{P}=0.0295$, respectively).

Next, the adherence experiments were repeated using the unencapsulated S. pneumoniae strain 3.8-DW (Fig. 1B). Adhesion to the A549 cells was time-dependent ( $r=0.9835$, $\mathrm{P}=0.0165)$ and adhesion to BEAS-2B cells demonstrated a tendency toward time-dependency ( $\mathrm{r}=0.941, \mathrm{P}=0.059$; Fig. 1B). Analysis of all curves revealed that 3.8-DW adhesion to A549 cells was significantly greater compared with the adhesion to the other cell types (A549 vs. nasal, $\mathrm{P}=0.0020$; A549 vs. oral, $\mathrm{P}=0.0001 ; \mathrm{A} 549$ vs. BEAS-2B, $\mathrm{P}<0.0001)$. In addition, analysis of the individual time points revealed that adhesion of 3.8-DW to nasal cells was significantly greater than to BEAS-2B cells at the 15,30 and 60 min time points $(\mathrm{P}=0.0002, \mathrm{P}<0.0001$ and $\mathrm{P}=0.0279$, respectively; Fig. $1 \mathrm{~B}$ and $\mathrm{C}$ ).

Invasion of the encapsulated S. pneumoniae WU2 strain and its unencapsulated derivative strain $3.8-D W$ to primary and secondary respiratory epithelial cells. In order to determine the extent of invasion of the WU2 strain to the cultured cells, antibiotics were added to the cell cultures at the denoted time points for $45 \mathrm{~min}$ prior to determination of bacterial count. Notably, the invasion of nasal cells compared with all other cells types increased within the first 60 min reaching the significance of $\mathrm{P}<0.0001$ at $30 \mathrm{~min}$, and decreased thereafter (Fig. 2A), possibly mimicking the transcytosis process that occurs in nasal mucosal cells. However, after $60 \mathrm{~min}$ the invasion of nasal cells remained significantly greater in comparison to the other cells types $(\mathrm{P}<0.0001)$. Cell invasion of A549 and BEAS-2B cells was time-dependent ( $r=0.9728$, $\mathrm{P}=0.0054$; and $\mathrm{r}=0.9787, \mathrm{P}=0.0037$, respectively); however, the invasion of oral cells was not. Consistently, WU2 invasion of
BEAS-2B and A549 cells was significantly greater compared to the invasion of oral cells $(\mathrm{P}=0.002$ and $\mathrm{P}=0.0008$, respectively; Fig. 2A). The invasion of WU2 into BEAS-2B cells was not significantly different from the invasion of A549 cells at any of the examined time points.

The invasion of the 3.8-DW unencapsulated strain of A549 and to BEAS-2B cells was time-dependent ( $\mathrm{r}=0.9946$, $\mathrm{P}=0.0054$; and $\mathrm{r}=0.9798, \mathrm{P}=0.0202$, respectively; Fig. $2 \mathrm{~B}$ ). Analysis of all curves revealed that invasion of A549 cells was significantly higher when compared with nasal, oral and BEAS-2B cells $(\mathrm{P}=0.0004, \mathrm{P}=0.0208$ and $\mathrm{P}=0.0007$, respectively; Fig. 2B and C). 3.8-DW invasion of A549 cells at each time point was significantly greater compared with oral cells at 30,60 and $90 \mathrm{~min}(\mathrm{P}=0.0058, \mathrm{P}=0.0339$ and $\mathrm{P}=0.0209$, respectively). The invasion of 3.8-DW into A549 cells was significantly greater than into nasal cells at 60 and 90 min time points $(\mathrm{P}=0.0007$ and $\mathrm{P}=0.0001$, respectively). The invasion into A549 cells was significantly greater than into BEAS-2B cells at the 60 and 90 min time point $(\mathrm{P}<0.0001$ and $\mathrm{P}=0.0007$, respectively). A total of $90 \mathrm{~min}$ following inoculation, invasion of nasal cells decreased (Fig. 2B and C), similar to the decrease observed for the WU2 strain invasion of nasal cells (Fig. 2A). Invasion of nasal cells was not significantly different when compared with oral cells.

Adhesion and invasion of encapsulated and unencapsulated S. pneumoniae strains to A549 cells. The next aim of the study was to compare the adhesion to and invasion of A549 cells of selected encapsulated and unencapsulated S. pneumoniae strains. The encapsulated strains included the following: i) The WU2 serotype 3 strain, which has the thickest capsule among all strains tested in the current study, and is considered to be a highly invasive strain (53-55); ii) the D39-LM serotype, which is widely used for studying S. pneumoniae pathogenesis (28); iii) the 6B-RD serotype, which was isolated from the nasopharynx of a healthy child and was previously demonstrated to colonize the nasopharynx but not disseminate to the lungs or any other tissue (56,57); and iv) the 23F-RD serotype, which is considered to be pathogenic, as its capsule was included in the 7 valent conjugate vaccine (58). The unencapsulated strains included the 3.8-DW, which is a derived from WU2 (44) and the R6 strain (45), which was derived from the D39 strain. Although the results presented so far indicated that the encapsulated WU2 strain adhered and invaded most efficiently to nasal epithelial cells, these cells are very difficult to obtain and maintain. Therefore, the adhesion to and invasion of A549 cells by the various encapsulated and unencapsulated strains were assessed.

All strains indicated a time-dependent adhesion to A549 cells (WU2, $\mathrm{r}=0.9487, \mathrm{P}=0.0139$; D39-LM, $\mathrm{r}=0.9866, \mathrm{P}=0.0019 ; 6 \mathrm{~B}-\mathrm{RD}, \mathrm{r}=0.9809, \mathrm{P}=0.0032 ; 23 \mathrm{~F}-\mathrm{RD}$, $\mathrm{r}=0.9424, \mathrm{P}=0.0165 ; 3.8-\mathrm{DW}, \mathrm{r}=8955, \mathrm{P}=0.0399 ; \mathrm{R} 6, \mathrm{r}=0.9936$, $\mathrm{P}=0.0006$; Fig. 3A). A whole-curve comparison revealed that the adhesion of the unencapsulated strain 3.8-DW was significantly higher when compared to that of the encapsulated strains (6B-RD, $\mathrm{P}=0.004$; 23F-RD $\mathrm{P}<0.0001$; D39-LM, $\mathrm{P}<0.0001$; WU2, $\mathrm{P}<0.0001)$, but was not significantly different from the adhesion of the unencapsulated strain R6 (Fig. 3A). In addition, whole-curve analysis indicated that the adhesion of the R6 strain was significantly higher than the adhesion of 
A

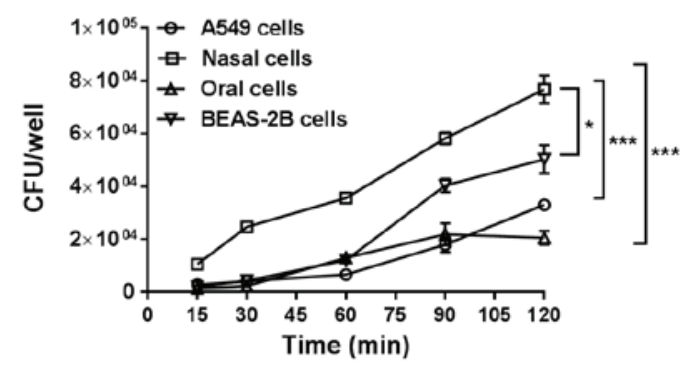

B

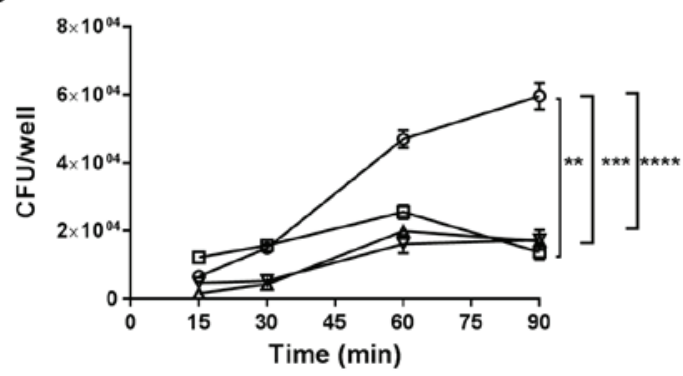

C

\begin{tabular}{|c|c|c|c|c|c|c|c|c|c|c|c|}
\hline \multirow{2}{*}{ Comparison } & \multicolumn{6}{|c|}{ wU2 } & \multicolumn{5}{|c|}{ 3.8DW } \\
\hline & $\begin{array}{l}\text { ANOVA of } \\
\text { Total Graph }\end{array}$ & 15 & 30 & 60 & 90 & 120 & $\begin{array}{l}\text { ANOVA of } \\
\text { Total Graph }\end{array}$ & 15 & 30 & 60 & 90 \\
\hline A549 vs. Nasal & $=0.0003$ & $<0.0001$ & $<0.0001$ & $<0.0001$ & $=0.0001$ & -0.0002 & $=0.0020$ & -0.0016 & $=0.9316$ (ns) & $<0.0001$ & $<0.0001$ \\
\hline A549 vs. Oral & $=0.9932$ (ns) & $=0.0715$ & $=0.0614$ (ns) & $=0.0295$ & $=0.8145$ (ns) & $=0.1319$ (ns) & $=0.0001$ & $=0.0139$ & $<0.0001$ & $<0.0001$ & $<0.0001$ \\
\hline A549 vs. BEAS-2B & $=0.3901$ (ns) & -0.3800 ) & $=0.9983(\mathrm{~ns})$ & $=0.0651$ (ns) & $=0.0024$ & -0.0295 & $<0.0001$ & $=0.4334$ (ns) & $<0.0001$ & $<0.0001$ & $<0.0001$ \\
\hline Nasal vs. Oral & $=0.0001$ & $<0.0001$ & $<0.0001$ & $<0.0001$ & $=0.0003$ & $<0.0001$ & $=0.5561$ (ns) & $<0.0001$ & $<0.0001$ & $=0.2651$ (ns) & $=0.7918$ (ns) \\
\hline Nasal vs. BEAS-2B & $=0.0193$ & $<0.0001$ & $<0.0001$ & $<0.0001$ & $=0.0363$ & $=0.0080$ & $=0.4687$ (ns) & $=0.0002$ & $<0.0001$ & $=0.0279$ & $=0.7431$ (ns) \\
\hline Oral vs. BEAS-2B & $=0.2447(\mathrm{~ns})$ & $=0.6694$ (ns) & $=0.0473$ & $=0.9476$ (ns) & $=0.0090$ & $=0.0008$ & $=0.9996$ (ns) & $=0.1514$ (ns) & $=0.9042(\mathrm{~ns})$ & $=0.6427(\mathrm{~ns})$ & $=0.9998$ (ns) \\
\hline
\end{tabular}

Figure 1. Adhesion of the encapsulated S. pneumoniae strain WU2 and its unencapsulated derivative strain 3.8-DW to A549, oral, nasal and BEAS-2B respiratory epithelial cells. (A) Adhesion of WU2 increased in a time-dependent manner in all cultured epithelial cells examined (nasal cells, $\mathrm{r}=0.9995$, $\mathrm{P}=0.0005$; oral cells, $\mathrm{r}=0.9461, \mathrm{P}=0.0149$; A549 cells, $\mathrm{r}=0.948, \mathrm{P}<0.02$; BEAS-2B cells, $\mathrm{r}=0.9707, \mathrm{P}=0.006)$. * $\mathrm{P}<0.05$ and ${ }^{* * * *} \mathrm{P}<0.001$. $(\mathrm{B}) \mathrm{The}$ adhesion of the unencapsulated S. pneumoniae strain 3.8-DW to A549 cells was time-dependent $(\mathrm{r}=0.9835$, $\mathrm{P}=0.0165)$, and adhesion to BEAS-2B cells demonstrated a tendency to be time-dependent $(\mathrm{r}=0.941, \mathrm{P}=0.059) .{ }^{* *} \mathrm{P}<0.01$; ${ }^{* * *} \mathrm{P}<0.001$; and ${ }^{* * * *} \mathrm{P}<0.0001$. (C) Statistical analysis for WU2 and $3.8 \mathrm{DW}$ adhesion for whole curve analysis comparisons (ANOVA of total graph) and at each time point. CFU, colony-forming units; S. pneumoniae; Streptococcus pneumonia; ANOVA, analysis of variance.

any of the encapsulated strains (23F-RD, $\mathrm{P}=0.004$; D39-LM, $\mathrm{P}<0.0001$; WU2, $\mathrm{P}=0.0007$ ) except for 6B-RD (Fig 3A). Significant differences in adherence among the unencapsulated 3.8-DW and encapsulated strains were observed at each of the individual time points examined except for 3.8-DW vs. 6B-RD at the 30 min time point. The strain 3.8-DW adhered more efficiently to the A549 cells up to $60 \mathrm{~min}$ of incubation. The adherence of the unencapsulated R6-RD was significantly greater than the encapsulated strains in all time points after 15 min of incubation. The adhesion of 6B-RD was significantly greater than that of the 23F-RD between 30 and 60 min of incubation, D39 after 15 min of incubation and WU2 strains at the 30 min time point.

The invasion of the 6B-RD, R6, D39-LM, and WU2 strains to the A549 cells was time-dependent (6B-RD, $\mathrm{r}=0.9416$, $\mathrm{P}=0.0168 ; \mathrm{R} 6, \mathrm{r}=0.9628, \mathrm{P}<0.0086$; D39-LM, $\mathrm{r}=0.9588$, $\mathrm{P}=0.01$; WU2, $\mathrm{r}=0.9728, \mathrm{P}<0.0054$; Fig. $3 \mathrm{~B})$. The invasion of the unencapsulated 3.8-DW strain was significantly greater compared with all the other strains assessed, by whole-curve analysis and at each of the examined time points, except in comparison to R6-DW at the $30 \mathrm{~min}$ time point (Fig. 3B and C).

\section{Discussion}

Cell lines are frequently used to understand the interactions between $S$. pneumoniae and its host (26,27,52,59-64). Notably, the lung-derived adenocarcinoma A549 cell line and the virus-transformed BEAS-2B bronchial cell line have been used for studying the function of virulence factors and the alterations that take place in the bacterium and the host cell upon bacteria-host interactions $(3,65-68)$. However, the suitability of these cell lines as in vitro models for investigating the interaction between $S$. pneumoniae and nasal or lung mucosal cells has not been verified directly. To the best of our knowledge, the present study is the first to demonstrate that the extent of adhesion and invasion of a highly encapsulated pathogenic $S$. pneumoniae strain (WU2) into nasal cells is superior in comparison to the extent of its adhesion and invasion into primary oral cells and into the cancer-derived or virus-transformed respiratory cell lines.

The adhesion of $S$. pneumoniae to the upper respiratory tract is a prerequisite for its colonization and is therefore considered to be a major risk factor for the development of pneumococcal disease $(3,69,70)$. The respiratory epithelial cells are the first line of defense of the innate immune system, and the interaction between pneumococci and the respiratory epithelial cells activates signal transduction cascades, in which p38 mitogen-activated protein kinase-dependent nuclear factor- $\kappa \mathrm{B}$ activation upregulates the expression of interleukin-8 (71). The activation of this cascade may be the result of the bacteria binding to innate immune system-associated pattern recognition receptors on the surface of mammalian cells (e.g. TLRs) (72), or to intracellular pattern recognition receptors, such as the nucleotide-binding oligomerization domain proteins (73). In addition, S. pneumoniae may bind to additional human membrane receptors, which are capable of activating different signal transduction pathways (74), which may increase cytokine expression. As a result, PAF-R expression is increased, which increases the binding of S. pneumoniae to the cells (29). 
A

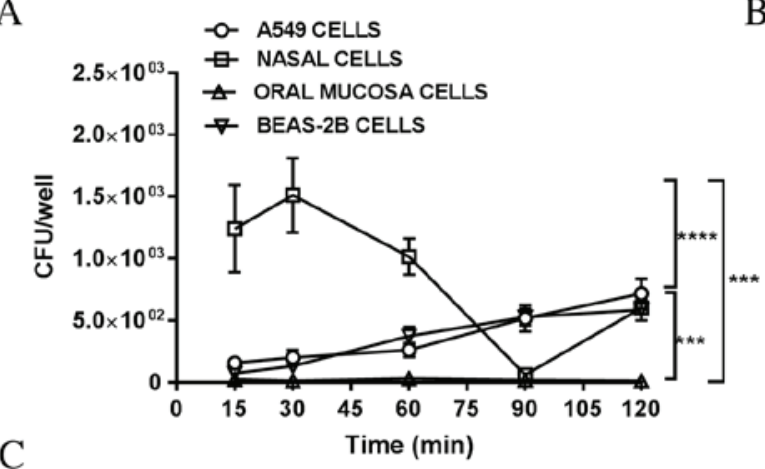

B

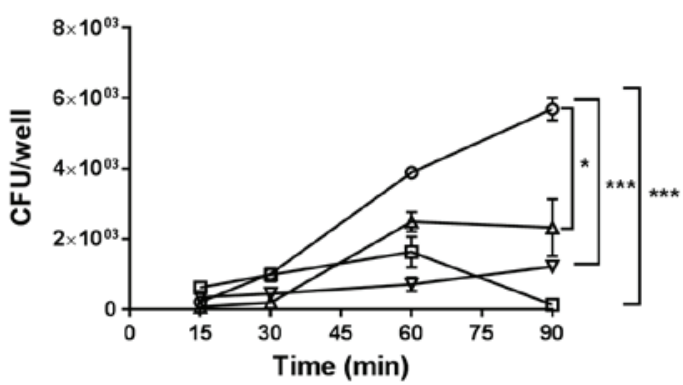

\begin{tabular}{|c|c|c|c|c|c|c|c|c|c|c|c|}
\hline Tir & \multicolumn{6}{|c|}{ WU2 } & \multicolumn{5}{|c|}{$3.8 \mathrm{DW}$} \\
\hline & $\begin{array}{l}\text { ANOVA of } \\
\text { Total Graph }\end{array}$ & 15 & 30 & 60 & 90 & 120 & $\begin{array}{l}\text { ANOVA of } \\
\text { Total Graph }\end{array}$ & 15 & 30 & 60 & 90 \\
\hline A 549 vs. Nasal & $<0.0001$ & 0.0003 & $<0.0001$ & $<0.0001$ & $=0.0001$ & $=0.3321$ (ns) & $=0.0004$ & $<0.0001$ & 0.9983 (ns) & $=0.0007$ & 0.0001 \\
\hline A549 vs. Oral & $=0.0008$ & $=0.7305$ (ns) & $-0.2829(\mathrm{~ns})$ & -0.0729 (ns) & $<0.0001$ & $<0.0001$ & $=0.0208$ & -0.1476 (ns) & 0.0058 & -0.0339 & 0.0209 \\
\hline A549 vs. BEAS-2B & $=0.9837(\mathrm{~ns})$ & $=0.9142(\mathrm{~ns})$ & $=0.8994$ (ns) & $=0.5571(\mathrm{~ns})$ & $=0.9970(\mathrm{~ns})$ & $=0.1539$ (ns) & $=0.0007$ & $=0.1593(\mathrm{~ns})$ & $0.0597(\mathrm{~ns})$ & 40.0001 & 0.0007 \\
\hline Nasal vs. Oral & $<0.0001$ & $<0.0001$ & $<0.0001$ & $<0.0001$ & $=0.8868(\mathrm{~ns})$ & $<0.0001$ & $=0.7250(\mathrm{~ns})$ & $<0.0001$ & 0.0038 & $=0.2241(\mathrm{~ns})$ & 0.4557 (ns) \\
\hline Nasal vs. BEAS-2B & $<0.0001$ & $=0.0001$ & $<0.0001$ & $<0.0001$ & $<0.0001$ & $=0.9932(\mathrm{~ns})$ & $=0.9956(\mathrm{~ns})$ & $=0.0035$ & 0.0497 & $=0.1789$ (ns) & 0.9852 (ns) \\
\hline Oral vs. BEAS-2B & $=0.0020$ & -0.9723 (ns) & $-0.6268(\mathrm{~ns})$ & -0.0078 & $<0.0001$ & $<0.0001$ & $=0.6551(\mathrm{~ns})$ & $=0.0036$ & 0.6117 (ns) & -0.0071 & $0.6920(\mathrm{~ns})$ \\
\hline
\end{tabular}

Figure 2. Invasion of the encapsulated S. pneumoniae strain WU2 and its unencapsulated derivative strain 3.8-DW to A549, nasal, oral and BEAS-2B respiratory epithelial cells. In order to determine invasion capabilities, extracellular bacteria were eliminated by adding antibiotics to the culture at the denoted time points, for 45 min prior to determination of bacterial counts. (A) Invasion of WU2 strain to cells at the indicated time points. The invasion of nasal cells vs. all other cells types was significantly greater within the first $60 \mathrm{~min}$, reaching the significance of $\mathrm{P}<0.0001$ at 30 min. Cell invasion increased continuously in $\mathrm{A} 549$ and in BEAS-2B cells ( $\mathrm{r}=0.9728, \mathrm{P}=0.0054$; and $\mathrm{r}=0.9787, \mathrm{P}=0.0037$, respectively). ( $\mathrm{B}$ ) Invasion of the unencapsulated strain $3.8 \mathrm{DW}$ to $\mathrm{A} 549$ and BEAS-2B cells was time-dependent $(r=0.9946, P=0.0054$; and $r=0.9798 \mathrm{P}=0.0202$, respectively). Analysis of all curves indicated that invasion of A549 cells was significantly more efficient than to nasal, oral, and BEAS-2B cells $(\mathrm{P}=0.0004, \mathrm{P}=0.0208$ and $\mathrm{P}=0.0007$, respectively). No significant differences in invasion efficiency were observed among the nasal, oral and BEAS-2B cell types. ${ }^{*} \mathrm{P}<0.05 ;{ }^{* * *} \mathrm{P}<0.001$; and ${ }^{* * * *} \mathrm{P}<0.0001$. (C) Statistical analysis for WU2 and 3.8DW invasion for whole curve analysis comparisons (ANOVA of total graph) and at each time point. CFU, colony-forming units; S. pneumoniae; Streptococcus pneumoniae; ANOVA, analysis of variance; ns, non significant.

In the current study, the WU2 strain adhered to all cell types in a time-dependent manner. The adhesion of WU2 to nasal cells was more efficient than the adhesion to other cells tested throughout the incubation period. In addition, WU2 invasion of nasal cells was significantly more efficient when compared with the other cell types examined. Invasion of the WU2 strain to the A549 and BEAS-2B cell lines was significantly higher than its invasion of oral cells. At $30 \mathrm{~min}$ following inoculation of nasal cells with the WU2 strain, a decline in the number of bacteria in these cells was observed, which decreased further at 60 and 90 min time points. Following adherence, S. pneumoniae is able to invade nasal cells by binding of bacterial phosphorylcholine or CbpA to the PAF-R of the host cell (29); the latter also binds to the $\operatorname{pIgR}(33)$, which allows subsequent exploitation of the recycling pathways. This facilitates transcytosis through the mucosal epithelial cell layer, and leads to the development of invasive disease. PAF-R is present in epithelial and endothelial cells $(29,75,76)$. The authors of the current study hypothesized that adhesion and invasion of $S$. pneumoniae strains to nasal cells may occur through these receptors or through other, as yet unknown receptors, which recycle and expel the WU2 strain more efficiently from the nasal cells than from the other types of cells examined. It has been demonstrated that S. pneumoniae adhere to and penetrate the nasopharynx to gain access to the middle ear via the Eustachian tube $(77,78)$. Thus, bacterial strains capable of invading nasopharyngeal cells may be those that disseminate and cause invasive disease (79). Out of all cell types examined in the present study, the adhesion and invasion of the WU2 strain to oral cells was the least efficient. The oral mucosa is not a primary site for S. pneumoniae colonization, although adhesion of $S$. pneumoniae to primary oral cells in vitro has been reported (80). Ultimately, differences in capsule size or the differential expression of virulence factors involved in the invasion process, may explain the ability of pathogenic pneumococci to adhere and invade different types of respiratory epithelial cells in different manners.

The adhesion of the unencapsulated strain 3.8-DW (a derivative of the encapsulated WU2 strain) (81) to A549 cells was time-dependent. However, unlike the WU2 strain, the 3.8-DW strain most efficiently adhered to and invaded A549 cells. This alteration in adhesion and invasion preference may be due to the exposure of surface proteins that are otherwise masked by the capsule, which is a major virulence factor that protects the bacterium from phagocytosis and prolongs its survival in phagocytes $(81,82)$. The authors attribute these differences in adhesion and invasion to the absence of the capsule, which allows the cell wall proteins to be exposed and available for interaction with the host cells. It has not yet been determined whether there are any genetic differences between the encapsulated and their unencapsulated derivatives. In addition, a different pattern of mRNA and protein expression in the unencapsulated strain compared with the parental strain may exist. 
A

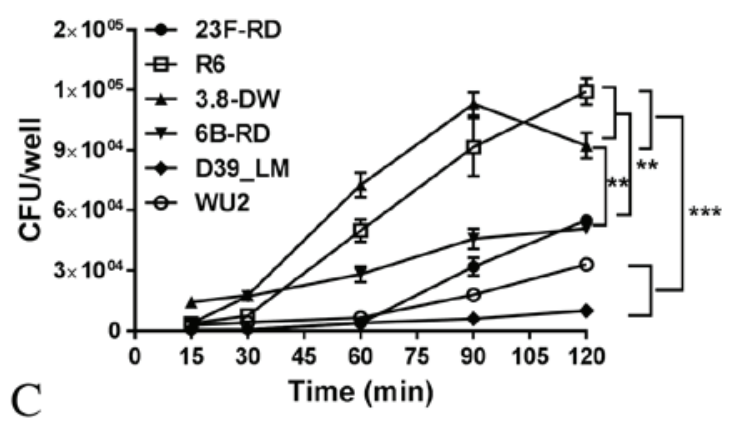

B

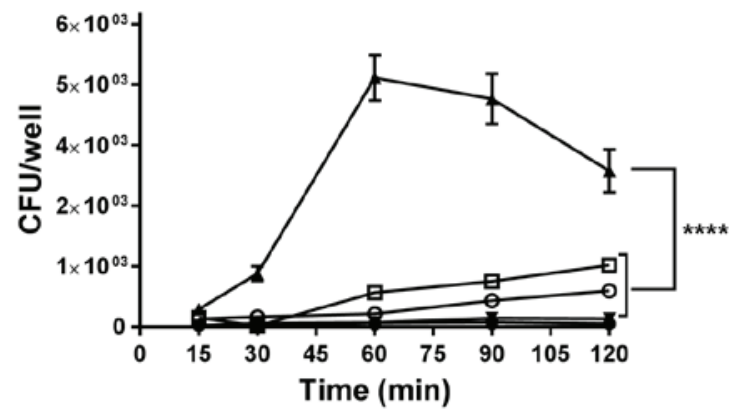

\begin{tabular}{|c|c|c|c|c|c|c|c|c|c|c|c|c|}
\hline \multirow{2}{*}{ Comparison } & \multicolumn{6}{|c|}{ Adhesion } & \multicolumn{6}{|c|}{ Invasion } \\
\hline & $\begin{array}{c}\text { ANOVA of } \\
\text { Total } \\
\text { Graph }\end{array}$ & 15 & 30 & 60 & 90 & 120 & $\begin{array}{c}\text { ANOVA of } \\
\text { Total } \\
\text { Graph }\end{array}$ & 15 & 30 & 60 & 90 & 120 \\
\hline $3.8 \mathrm{DW}$ vs. $6 \mathrm{~B}$ & $=0.0040$ & $<0.0001$ & 0.9936(ns) & $<0.0001$ & $<0.000 \mid$ & $<0.0001$ & $<0.0001$ & $=0.0001$ & $<0.0001$ & $<0.0001$ & $=0.0012$ & $<0.0001$ \\
\hline $3.8 \mathrm{DW}$ vs. $23 \mathrm{~F}$ & $<0.0001$ & $<0.0001$ & $<0.0001$ & $<0.0001$ & $<0.0001$ & $=0.0001$ & $<0.0001$ & $<0.0001$ & $<0.0001$ & $<0.0001$ & $=0.0010$ & $<0.0001$ \\
\hline $3.8 \mathrm{DW}$ vs. R6 & $=0.9541(\mathrm{~ns})$ & $<0.0001$ & $<0.0001$ & $=0.0158$ & 0.2472 & $=0.0042$ & $<0.0001$ & $0.0564(\mathrm{~ns})$ & $<0.0001$ & $<0.0001$ & $=0.0115$ & $=0.0003$ \\
\hline 3.8DW vs. D39 & $<0.0001$ & $<0.0001$ & $<0.0001$ & $<0.0001$ & $<0.0001$ & $<0.0001$ & $<0.0001$ & $<0.0001$ & $<0.0001$ & $<0.0001$ & $=0.0019$ & $<0.0001$ \\
\hline $3.8 \mathrm{DW}$ vs. WU2 & $<0.0001$ & $<0.0001$ & $<0.0001$ & 40.0001 & $<0.0001$ & $<0.0001$ & $<0.0001$ & $=0.0369$ & $<0.0001$ & $<0.0001$ & $=0.0036$ & $<0.0001$ \\
\hline $6 \mathrm{~B}$ vs. $23 \mathrm{~F}$ & -0.8730 (ns) & $=0.0998(\mathrm{~ns})$ & $<0.0001$ & $=0.0186$ & $=0.7550$ (ns) & $=0.9883(\mathrm{~ns})$ & $>0.9999(\mathrm{~ns})$ & $>0.9999$ (ns) & $=0.9989$ (ns) & $>0.9999$ (ns) & $>0.9999$ (ns) & $=0.9998$ (ns) \\
\hline 6B vs. R6 & $-0.1042(\mathrm{~ns})$ & $>0.9999$ (ns) & $<0.0001$ & $=0.0420$ & $=0.0031$ & $<0.0001$ & $-0.5510(\mathrm{~ns})$ & $=0.0982(\mathrm{~ns})$ & $=0.9996$ (ns) & $=0.6581$ (ns) & $=0.9129(\mathrm{~ns})$ & $=0.0898$ (ns) \\
\hline 6B vs. D39 & $-0.1111(\mathrm{~ns})$ & $=0.1373(\mathrm{~ns})$ & $<0.0001$ & $=0.0193$ & -0.0110 & $=0.0001$ & $-0.9996(\mathrm{~ns})$ & -0.9952 (ns) & $=0.9968$ (ns) & $>0.9999$ (ns) & $>0.9999$ (ns) & $=0.9984$ (ns) \\
\hline $6 \mathrm{~B}$ vs. WU2 & $=0.5822(\mathrm{~ns})$ & $=0.9603$ (ns) & $<0.0001$ & $=0.0707(\mathrm{~ns})$ & $=0.1200$ (ns) & $=0.1412(\mathrm{~ns})$ & $=0.9503(\mathrm{~ns})$ & $=0.2984$ (ns) & $=0.9191(\mathrm{~ns})$ & $=0.9973$ (ns) & $=0.9966$ (ns) & $=0.6732$ (ns) \\
\hline 23 F vs. R6 & $=0.0040$ & $=0.1321(\mathrm{~ns})$ & $<0.0001$ & $<0.0001$ & $=0.0002$ & $<0.0001$ & $=0.4537(\mathrm{~ns})$ & $=0.0697(\mathrm{~ns})$ & $>0.9999(\mathrm{~ns})$ & $=0.6520(\mathrm{~ns})$ & $=0.8748(\mathrm{~ns})$ & $=0.0533$ (ns) \\
\hline 23F vs. D39 & $=0.6917(\mathrm{~ns})$ & $>0.9999(\mathrm{~ns})$ & $>0.9999$ (ns) & $>0.9999$ (ns) & $=0.1702$ (ns) & $<0.0001$ & $>0.9999(\mathrm{~ns})$ & $=0.9994(\mathrm{~ns})$ & $>0.9999$ (ns) & $>0.9999$ (ns) & $>0.9999$ (ns) & $>0.9999$ (ns) \\
\hline $23 \mathrm{~F}$ vs. WU2 & $=0.9952(\mathrm{~ns})$ & $=0.3900$ (ns) & $=0.0194$ & $\Rightarrow 0.9988(\mathrm{~ns})$ & $=0.7563(\mathrm{~ns})$ & $=0.0422$ & $=0.9064(\mathrm{~ns})$ & $=0.2301(\mathrm{~ns})$ & $=0.7553(\mathrm{~ns})$ & $=0.9970$ (ns) & $=0.9915(\mathrm{~ns})$ & $=0.5146$ (ns) \\
\hline R6 vs. D39 & $<0.0001$ & $=0.1792(\mathrm{~ns})$ & $<0.0001$ & $<0.0001$ & $<0.0001$ & $<0.0001$ & $=0.3862(\mathrm{~ns})$ & $=0.0366$ & $>0.9999$ (ns) & $=0.5284(\mathrm{~ns})$ & $=0.8626$ (ns) & $=0.0400$ (ns) \\
\hline R6 vs. WU2 & $=0.0007$ & $=0.9833(\mathrm{~ns})$ & $=0.0240$ & $=0.0001$ & $<0.0001$ & $<0.0001$ & $=0.9698(\mathrm{~ns})$ & $=0.9974$ (ns) & $=0.8277$ (ns) & $=0.8885$ (ns) & $=0.9944$ (ns) & $=0.7506$ (ns) \\
\hline D39 vs. WU2 & $=0.9419$ (ns) & $=0.4858$ (ns) & $=0.0204$ & $=0.9990$ (ns) & $=0.8520$ (ns) & $=0.0332$ & $=0.8538$ (ns) & $=0.1381$ (ns) & $=0.7423$ (ns) & $=0.9840$ (ns) & $=0.9859$ (ns) & $=0.4338(\mathrm{~ns})$ \\
\hline
\end{tabular}

Figure 3. Adhesion and invasion of encapsulated and unencapsulated clinical and laboratory S. pneumoniae strains to A549 cells. (A) The S. pneumoniae unencapsulated strains 3.8-DW and R6, and the encapsulated strains 23F-RD, 6B-RD, WU2, and D39-LM, were incubated with A549 cells for 15, 30, 60, 90 or 120 min. All strains demonstrated time-dependent adhesion to the A549 cells (WU2, $r=0.9487, P=0.0139 ; \mathrm{D} 39-\mathrm{LM}, \mathrm{r}=0.9866, \mathrm{P}=0.0019 ; 6 \mathrm{~B}-\mathrm{RD}$, $\mathrm{r}=0.9809, \mathrm{P}=0.0032 ; 23 \mathrm{~F}-\mathrm{RD}, \mathrm{r}=0.9424, \mathrm{P}=0.0165 ; 3.8-\mathrm{DW}, \mathrm{r}=8955, \mathrm{P}=0.0399$; R6, $\mathrm{r}=0.9936, \mathrm{P}=0.0006$ ). (B) Invasion of the 6B-RD, R6, D39-LM, and WU2 strains to A549 cells was time-dependent (6B-RD, r=0.9416, $\mathrm{P}=0.0168 ; \mathrm{R} 6, \mathrm{r}=0.9628, \mathrm{P}<0.0086 ; \mathrm{D} 39-\mathrm{LM}, \mathrm{r}=0.9588, \mathrm{P}=0.01$; WU2, $\mathrm{r}=0.9728, \mathrm{P}<0.0054)$. The unencapsulated strain $3.8-\mathrm{DW}$ demonstrated the highest invasion capabilities out of all strains examined in the full-curve analysis. ${ }^{* *} \mathrm{P}<0.01 ;{ }^{* * *} \mathrm{P}<0.001$; and ${ }^{* * * *} \mathrm{P}<0.0001$. (C) Statistical analysis for adhesion and invasion of the full curve comparisons (ANOVA of total graph) and at each time point. CFU, colony-forming units; S. pneumoniae; Streptococcus pneumoniae; ANOVA, analysis of variance; ns, non significant.

Previous studies have suggested that the capsule prevents bacterial adhesion to epithelial cells $(62,83,84)$. In addition, partial capsule shedding at the site of adhesion is a prerequisite for S. pneumoniae adhesion and invasion, and variations in the capsule size of different strains or variants affects the extent of adhesion (22,85-88). In general, unencapsulated $S$. pneumoniae strains are less virulent than encapsulated strains; a phenomenon primarily associated to the lack of the capsular polysaccharide shield (89). However, infection with unencapsulated strains leads to streptococcal ocular keratitis in a rabbit model system (90) and conjunctivitis in humans (91).

The unencapsulated strains 3.8-DW and R6 demonstrated similar adhesion efficiencies in the A549 cells, and were significantly higher than that of the other encapsulated strains tested. These results are consistent with a previous study (22). In contrast to their similar adhesion capabilities, invasion of A549 cells by the R6 strain was as inefficient as that of the encapsulated strains when compared to the 3.8-DW strain. An increasing number of reports have identified non-encapsulated $S$. pneumoniae as a disease-causing pathogen (40). This phenomenon may originate from the introduction of the pneumococcal conjugate vaccine in 2000 , or from an improved identification of the smaller colonies of non-encapsulated S. pneumoniae in microbiology laboratories (40). Keller et al (40) described the different characteristics of non-encapsulated S. pneumoniae obtained from patients with nasopharyngeal colonization or invasive pneumococcal diseases. In addition, a recent report demonstrated the involvement of non-encapsulated $S$. pneumoniae as a cause of chronic adenoiditis (92).

In conclusion, the results of the present study provide evidence of an association between the ability of pathogenic encapsulated $S$. pneumoniae to adhere to and invade specific respiratory epithelial cells in vitro and the natural course of $S$. pneumoniae-induced diseases. In addition, the results demonstrate that alternative cell cultures may be used to further contribute to research concerning the interaction between $S$. pneumoniae and its host. Whereas the cancer-derived cell lines are informative, primary cultures may assist in deciphering specific interactions and the identification of molecules responsible for the affinity of $S$.pneumoniae to specific tissues. Furthermore, cell origin and type may cause differences that should be taken into consideration when drawing conclusions and translating to in vivo cell biology.

\section{Acknowledgements}

The present study was supported by The Israel Ministry of Health (grant nos. 4476, 5540 and 3000003867), BG Negev Technologies, Ben-Gurion University of the Negev (grant no. 80,904,101), The Center of Emerging Diseases (grant 
no. 2506), and the Israel Academy of Science (grant no. 613/04). This manuscript is written in the memory of Professor Nili Grossman.

\section{References}

1. Weinberger DM, Harboe ZB, Sanders EA, Ndiritu M, Klugman KP, Rückinger S, Dagan R, Adegbola R, Cutts F, Johnson HL, et al: Association of serotype with risk of death due to pneumococcal pneumonia: A meta-analysis. Clin Infect Dis 51: 692-699, 2010.

2. Harvey RM, Trappetti C, Mahdi LK, Wang H, McAllister LJ, Scalvini A, Paton AW and Paton JC: The variable region of pneumococcal pathogenicity island 1 is responsible for unusually high virulence of a serotype 1 isolate. Infect Immun 84: 822-832, 2016.

3. Vernatter J and Pirofski LA: Current concepts in host-microbe interaction leading to pneumococcal pneumonia. Curr Opin Infect Dis 26: 277-283, 2013.

4. Simell B, Auranen K, Kayhty H, Goldblatt D, Dagan R and O'Brien KL; Pneumococcal Carriage Group: The fundamental link between pneumococcal carriage and disease. Expert Rev Vaccines 11: 841-855, 2012.

5. van der Poll T and Opal SM: Pathogenesis, treatment, and prevention of pneumococcal pneumonia. Lancet 374: 1543-1556, 2009.

6. Kim L, McGee L, Tomczyk S and Beall B: Biological and epidemiological features of antibiotic-resistant Streptococcus pneumoniae in pre- and post-conjugate vaccine eras: A United States perspective. Clin Microbiol Rev 29: 525-552, 2016

7. Brauner A, Fridman O, Gefen O and Balaban NQ: Distinguishing between resistance, tolerance and persistence to antibiotic treatment. Nat Rev Microbiol 14: 320-330, 2016.

8. Hammitt LL, Bulkow LR, Singleton RJ, Nuorti JP, Hummel KB, Miernyk KM, Miernyk KM, Zanis C, Whaley $M$ and Romero-Steiner S: Repeat revaccination with 23-valent pneumococcal polysaccharide vaccine among adults aged 55-74 years living in Alaska: No evidence of hyporesponsiveness. Vaccine 29: 2287-2295, 2011.

9. Käyhty H and Eskola J: New vaccines for the prevention of pneumococcal infections. Emerg Infect Dis 2: 289-298, 1996.

10. Golden AR, Adam HJ and Zhanel GG; Canadian Antimicrobial Resistance A: Invasive Streptococcus pneumoniae in Canada, 2011-2014: Characterization of new candidate 15-valent pneumococcal conjugate vaccine serotypes $22 \mathrm{~F}$ and $33 \mathrm{~F}$. Vaccine 34 2527-2530, 2016

11. Jauneikaite E, Tocheva AS, Jefferies JM, Gladstone RA, Faust SN, Christodoulides M, Hibberd ML and Clarke SC: Current methods for capsular typing of Streptococcus pneumoniae. J Microbiol Methods 113: 41-49, 2015.

12. Geno KA, Gilbert GL, Song JY, Skovsted IC, Klugman KP, Jones C, Konradsen HB and Nahm MH: Pneumococcal capsules and their types: Past, present, and future. Clin Microbiol Rev 28: 871-899, 2015.

13. Hicks LA, Harrison LH, Flannery B, Hadler JL, Schaffner W, Craig AS, Jackson D, Thomas A, Beall B, Lynfield R, et al: Incidence of pneumococcal disease due to non-pneumococcal conjugate vaccine (PCV7) serotypes in the United States during the era of widespread PCV7 vaccination, 1998-2004. J Infect Dis 196: 1346-1354, 2007.

14. Dagan R: Serotype replacement in perspective. Vaccine 27: (Suppl 3) C22-C24, 2009.

15. Shak JR, Vidal JE and Klugman KP: Influence of bacterial interactions on pneumococcal colonization of the nasopharynx. Trends in Microbiol 21: 129-135, 2013.

16. Hammerschmidt S: Adherence molecules of pathogenic pneumococci. Curr Opin Microbiol 9: 12-20, 2006.

17. Paterson GK and Orihuela CJ: Pneumococcal microbial surface components recognizing adhesive matrix molecules targeting of the extracellular matrix. Mol Microbiol 77: 1-5, 2010.

18. Harfouche C, Filippini S, Gianfaldoni C, Ruggiero P, Moschioni M, Maccari S, Pancotto L, Arcidiacono L, Galletti B, Censini S, et al: RrgB321, a fusion protein of the three variants of the pneumococcal pilus backbone rrgb, is protective in vivo and elicits opsonic antibodies. Infect Immun 80: 451-460, 2012.
19. MoschioniM,DonatiC,MuzziA,MasignaniV,CensiniS,HanageWP Bishop CJ, Reis JN, Normark S, Henriques-Normark B, et al: Streptococcus pneumoniae contains $3 \mathrm{rlrA}$ pilus variants that are clonally related. J Infect Dis 197: 888-896, 2008.

20. Basset A, Zhang F, Benes C, Sayeed S, Herd M, Thompson C, Golenbock DT, Camilli A and Malley R: Toll-like receptor (TLR) 2 mediates inflammatory responses to oligomerized RrgA pneumococcal pilus type 1 protein. J Biol Chem 288: 2665-2675, 2013.

21. Bagnoli F, Moschioni M, Donati C, Dimitrovska V, Ferlenghi I, Facciotti C, Muzzi A, Giusti F, Emolo C, Sinisi A, et al: A second pilus type in Streptococcus pneumoniae is prevalent in emerging serotypes and mediates adhesion to host cells. J Bacteriol 190: 5480-5492, 2008.

22. Hammerschmidt S, Wolff S, Hocke A, Rosseau S, Muller E and Rohde M: Illustration of pneumococcal polysaccharide capsule during adherence and invasion of epithelial cells. Infect Immun 73: 4653-4667, 2005.

23. Berry AM and Paton JC: Sequence heterogeneity of PsaA, a 37-kilodalton putative adhesin essential for virulence of Streptococcus pneumoniae. Infect Immun 64: 5255-5262, 1996.

24. Anderton JM, Rajam G, Romero-Steiner S, Summer S, Kowalczyk AP, Carlone GM, Sampson JS and Ades EW: E-cadherin is a receptor for the common protein pneumococcal surface adhesin A (PsaA) of Streptococcus pneumoniae. Microb Pathog 42: 225-236, 2007.

25. Pracht D, Elm C, Gerber J, Bergmann S, Rohde M, Seiler M, Kim KS, Jenkinson HF, Nau R and Hammerschmidt S: PavA of Streptococcus pneumoniae modulates adherence, invasion, and meningeal inflammation. Infect Immun 73: 2680-2699, 2005.

26. Blau K, Portnoi M, Shagan M, Kaganovich A, Rom S, Kafka D, Chalifa Caspi V, Porgador A, Givon-Lavi N, Gershoni JM, et al: Flamingo cadherin: A putative host receptor for Streptococcus pneumoniae. J Infect Dis 195: 1828-1837, 2007.

27. Muchnik L, Adawi A, Ohayon A, Dotan S, Malka I, Azriel S, Shagan M, Portnoi M, Kafka D, Nahmani H, et al: NADH oxidase functions as an adhesin in Streptococcus pneumoniae and elicits a protective immune response in mice. PloS One 8: e61128, 2013.

28. Mizrachi Nebenzahl Y, Blau K, Kushnir T, Shagan M, Portnoi M, Cohen A, Azriel S, Malka I, Adawi A, Kafka D, et al: Streptococcus pneumoniae cell-wall-localized phosphoenolpyruvate protein phosphotransferase can function as an adhesin: Identification of its host target molecules and evaluation of its potential as a vaccine. PloS One 11: e0150320, 2016.

29. Cundell DR, Gerard NP, Gerard C, Idanpaan-Heikkila I and Tuomanen EI: Streptococcus pneumoniae anchor to activated human cells by the receptor for platelet-activating factor. Nature 377: 435-438, 1995.

30. Shivshankar P, Boyd AR, Le Saux CJ, Yeh IT and Orihuela CJ: Cellular senescence increases expression of bacterial ligands in the lungs and is positively correlated with increased susceptibility to pneumococcal pneumonia. Aging Cell 10: 798-806, 2011.

31. Nagaoka K, Yanagihara $\mathrm{K}$, Morinaga $\mathrm{Y}$, Nakamura $\mathrm{S}$, Harada T, Hasegawa H, Izumikawa K, Ishimatsu Y, Kakeya H, Nishimura M and Kohno S: Prevotella intermedia induces severe bacteremic pneumococcal pneumonia in mice with upregulated platelet-activating factor receptor expression. Infect Immun 82: 587-593, 2014.

32. Suri R, Periselneris J, Lanone S, Zeidler-Erdely PC, Melton G, Palmer KT, Andujar P, Antonini JM, Cohignac V, Erdely A, et al: Exposure to welding fumes and lower airway infection with Streptococcus pneumoniae. J Allergy Clin Immunol 137: 527-534. e7, 2016.

33. Rosenow C, Ryan P, Weiser JN, Johnson S, Fontan P, Ortqvist A and Masure HR: Contribution of novel choline-binding proteins to adherence, colonization and immunogenicity of Streptococcus pneumoniae. Mol Microbiol 25: 819-829, 1997.

34. Hammerschmidt S, Talay SR, Brandtzaeg P and Chhatwal GS: SpsA, a novel pneumococcal surface protein with specific binding to secretory immunoglobulin A and secretory component. Mol Microbiol 25: 1113-1124, 1997.

35. Brooks-Walter A, Briles DE and Hollingshead SK: The pspC gene of Streptococcus pneumoniae encodes a polymorphic protein, PspC, which elicits cross-reactive antibodies to PspA and provides immunity to pneumococcal bacteremia. Infect Immun 67: 6533-6542, 1999.

36. Gamez $G$ and Hammerschmidt S: Combat pneumococcal infections: Adhesins as candidates for protein-based vaccine development. Curr Drug Targets 13: 323-337, 2012. 
37. Plumptre CD, Ogunniyi AD and Paton JC: Polyhistidine triad proteins of pathogenic streptococci. Trends Microbiol 20: 485-493, 2012.

38. Khan MN and Pichichero ME: Vaccine candidates PhtD and PhtE of Streptococcus pneumoniae are adhesins that elicit functional antibodies in humans. Vaccine 30: 2900-2907, 2012.

39. Kallio A, Sepponen K, Hermand P, Denoël P, Godfroid F and Melin M: Role of Pht proteins in attachment of Streptococcus pneumoniae to respiratory epithelial cells. Infect Immun 82: 1683-1691, 2014.

40. Keller LE, Robinson DA and McDaniel LS: Nonencapsulated Streptococcus pneumoniae: Emergence and pathogenesis. MBio 7: e01792, 2016.

41. Alloing G, de Philip P and Claverys JP: Three highly homologous membrane-bound lipoproteins participate in oligopeptide transport by the Ami system of the gram-positive Streptococcus pneumoniae. J Mol Biol 241: 44-58, 1994.

42. Claverys JP, Grossiord B and Alloing G: Is the Ami-AliA/B oligopeptide permease of Streptococcus pneumoniae involved in sensing environmental conditions? Res Microbiol 151: 457-463, 2000.

43. Park IH, Kim KH, Andrade AL, Briles DE, McDaniel LS and Nahm MH: Nontypeable pneumococci can be divided into multiple cps types, including one type expressing the novel gene pspK. mBio 3: e00035-e00112, 2012.

44. Watson DA and Musher DM: Interruption of capsule production in Streptococcus pneumonia serotype 3 by insertion of transposon Tn916. Infect Immun 58: 3135-3138, 1990.

45. Carvalho SM, Kuipers OP and Neves AR: Environmental and nutritional factors that affect growth and metabolism of the pneumococcal serotype 2 strain D39 and its nonencapsulated derivative strain R6. PloS One 8: e58492, 2013.

46. Ueda M, Hata K, Horie K and Torii S: The potential of oral mucosal cells for cultured epithelium: A preliminary report. Ann Plast Surg 35: 498-504, 1995.

47. Rheinwald JG and Green H: Serial cultivation of strains of human epidermal keratinocytes: The formation of keratinizing colonies from single cells. Cell 6: 331-343, 1975.

48. Rheinwald J: Methods for clonal growth and serial cultivation of normal human epidermal keratinocytes and mesothelial cells. In: Cell Growth and Division: A Practical Approach. Baserga R (ed). IRL Press, Oxford, pp 81-94, 1989.

49. Lieber M, Smith B, Szakal A, Nelson-Rees W and Todaro G: A continuous tumor-cell line from a human lung carcinoma with properties of type II alveolar epithelial cells. Int J Cancer 17: 62-70, 1976.

50. Balis JU, Bumgarner SD, Paciga JE, Paterson JF and Shelley SA: Synthesis of lung surfactant-associated glycoproteins by A549 cells: Description of an in vitro model for human type II cell dysfunction. Exp Lung Res 6: 197-213, 1984.

51. Asano K, Chee CB, Gaston B, Lilly CM, Gerard C, Drazen JM, Stamler JS: Constitutive and inducible nitric oxide synthase gene expression, regulation, and activity in human lung epithelial cells. Proc Natl Acad Sci USA 91: 10089-10093, 1994.

52. Bergmann S, Schoenen $\mathrm{H}$ and Hammerschmidt S: The interaction between bacterial enolase and plasminogen promotes adherence of Streptococcus pneumoniae to epithelial and endothelial cells. Int J Med Microbiol 303: 452-462, 2013.

53. Briles DE, Nahm M, Schroer K, Davie J, Baker P, Kearney J and Barletta R: Antiphosphocholine antibodies found in normal mouse serum are protective against intravenous infection with type 3 Streptococcus pneumoniae. J Exp Med 153: 694-705, 1981.

54. Mizrachi Nebenzahl Y, Porat N, Lifshitz S, Novick S, Levi A, Ling E, Liron O, Mordechai S, Sahu RK and Dagan R: Virulence of Streptococcus pneumoniae may be determined independently of capsular polysaccharide. FEMS Microbiol Lett 233: 147-152, 2004.

55. Sahu RK, Mordechai S, Pesakhov S, Dagan R and Porat N: Use of FTIR spectroscopy to distinguish between capsular types and capsular quantities in Streptococcus pneumoniae. Biopolymers 83: 434-442, 2006.

56. Mizrachi-Nebenzahl Y, Lifshitz S, Teitelbaum R, Novick S, Levi A, Benharroch D, Ling E and Dagan R: Differential activation of the immune system by virulent Streptococcus pneumoniae strains determines recovery or death of the host. Clin Exp Immunol 134: 23-31, 2003.

57. Ling E, Feldman G, Dagan R and Mizrachi-Nebenzahl Y: Cytokine mRNA expression in pneumococcal carriage, pneumonia, and sepsis in young mice. J Infect Dis 188: 1752-1766, 2003.
58. Whitney CG, Farley MM, Hadler J, Harrison LH, Bennett NM, Lynfield R, Reingold A, Cieslak PR, Pilishvili T, Jackson D, et al: Decline in invasive pneumococcal disease after the introduction of protein-polysaccharide conjugate vaccine. N Engl J Med 348: 1737-1746, 2003

59. Daniely D, Portnoi M, Shagan M, Porgador A, Givon-Lavi N, Ling E, Dagan R and Mizrachi Nebenzahl Y: Pneumococcal 6-phosphogluconate-dehydrogenase, a putative adhesin, induces protective immune response in mice. Clin Exp Immunol 144: 254-163, 2006.

60. Mizrachi Nebenzahl Y, Bernstein A, Portnoi M, Shagan M, Rom S, Porgador A and Dagan R: Streptococcus pneumoniae surface-exposed glutamyl tRNA synthetase, a putative adhesin, is able to induce a partially protective immune response in mice. J Infect Dis 196: 945-953, 2007.

61. Zahlten J, Kim YJ, Doehn JM, Pribyl T, Hocke AC, Garcia P, Hammerschmidt S, Suttorp N, Hippenstiel S and Hübner RH: Streptococcus pneumoniae-induced oxidative stress in lung epithelial cells depends on pneumococcal autolysis and is reversible by resveratrol. J Infect Dis 211: 1822-1830, 2015.

62. Adamou JE, Wizemann TM, Barren P and Langermann S: Adherence of Streptococcus pneumoniae to human bronchial epithelial cells (BEAS-2B). Infect Immun 66: 820-822, 1998.

63. Robson RL, Reed NA and Horvat RT: Differential activation of inflammatory pathways in A549 type II pneumocytes by Streptococcus pneumoniae strains with different adherence properties. BMC Infect Dis 6: 71, 2006.

64. Mushtaq N, Ezzati M, Hall L, Dickson I, Kirwan M, Png KM, Mudway IS and Grigg J: Adhesion of Streptococcus pneumoniae to human airway epithelial cells exposed to urban particulate matter. J Allergy Clin Immunol 127: 1236-1242, 2011.

65. Li-Korotky HS, Lo CY, Zeng FR, Lo D and Banks JM: Interaction of phase variation, host and pressure/gas composition: Pneumococcal gene expression of PsaA, Spx B, Ply and Lyt A in simulated middle ear environments. Int J Pediatr Otorhinolaryngol 73: 1417-1422, 2009.

66. Statt S, Ruan JW, Huang CT, Wu R and Kao CY: Lipidome and transcriptome profiling of pneumolysin intoxication identifies networks involved in statin-conferred protection of airway epithelial cells. Sci Rep 5: 10624, 2015.

67. Li P, Shi J, He Q, Hu Q, Wang YY, Zhang LJ, Chan WT and Chen WX: Streptococcus pneumoniae induces autophagy through the inhibition of the PI3K-I/Akt/mTOR pathway and ROS hypergeneration in A549 cells. PloS One 10: e0122753, 2015.

68. Zahlten J, Herta T, Kabus C, Steinfeldt M, Kershaw O, García P, Hocke AC, Gruber AD, Hübner RH, Steinicke R, et al: Role of pneumococcal autolysin for KLF4 expression and chemokine secretion in lung epithelium. Am J Respir Cell Mol Biol 53: 544-554, 2015

69. Leiberman A, Dagan R, Leibovitz E, Yagupsky P and Fliss DM: The bacteriology of the nasopharynx in childhood. Int J Pediatr Otorhinolaryngol 49: (Suppl) S151-S153, 1999.

70. Siegel SJ and Weiser JN: Mechanisms of bacterial colonization of the respiratory tract. Annu Rev Microbiol 69: 425-444, 2015.

71. Schmeck B, Zahlten J, Moog K, van Laak V, Huber S, Hocke AC, Opitz B, Hoffmann E, Kracht M, Zerrahn J, et al: Streptococcus pneumoniae-induced p38 MAPK-dependent phosphorylation of RelA at the interleukin-8 promotor. J Biol Chem 279: 53241-53247, 2004.

72. Ratner AJ, Lysenko ES, Paul MN and Weiser JN: Synergistic proinflammatory responses induced by polymicrobial colonization of epithelial surfaces. Proc Natl Acad Sci USA 102: 3429-3434, 2005.

73. Opitz B, Püschel A, Schmeck B, Hocke AC, Rosseau S, Hammerschmidt S, Schumann RR, Suttorp N and Hippenstiel S: Nucleotide-binding oligomerization domain proteins are innate immune receptors for internalized Streptococcus pneumoniae. J Biol Chem 279: 36426-36432, 2004.

74. Iovino F, Brouwer MC, van de Beek D, Molema G and Bijlsma JJ: Signalling or binding: The role of the platelet-activating factor receptor in invasive pneumococcal disease. Cell Microbiol 15: 870-881, 2013.

75. Zhang JR, Mostov KE, Lamm ME, Nanno M, Shimida S, Ohwaki M and Tuomanen E: The polymeric immunoglobulin receptor translocates pneumococci across human nasopharyngeal epithelial cells. Cell 102: 827-837, 2000.

76. ElmC, Rohde M, Vaerman JP,Chhatwal GS and Hammerschmidt S: Characterization of the interaction of the pneumococcal surface protein SpsA with the human polymeric immunoglobulin receptor (hpIgR). Indian J Med Res 119: (Suppl) 61-65, 2004. 
77. Stenfors LE and Räisänen S: Bacterial adhesion to epithelial cells of the nasopharynx essential in the development of otitis media. Nord Med 107: 278-279, 1992 (In Swedish).

78. Stenfors LE and Räisänen S: In vivo attachment of Streptococcus pneumoniae and Haemophilus influenzae to nasopharyngeal epithelium in children. ORL J Otorhinolaryngol Relat Spec 54: 25-28, 1992.

79. Nelson AL, Roche AM, Gould JM, Chim K, Ratner AJ and Weiser JN: Capsule enhances pneumococcal colonization by limiting mucus-mediated clearance. Infect Immun 75: 83-90, 2007.

80. Mbaki N, Rikitomi N, Akiyama M and Matsumoto K: In vitro adherence of Streptococcus pneumoniae to oropharyngeal cells: Enhanced activity and colonization of the upper respiratory tract in patients with recurrent respiratory infections. Tohoku J Exp Med 157: 345-354, 1989.

81. McCullers JA and Tuomanen EI: Molecular pathogenesis of pneumococcal pneumonia. Front Biosci 6: D877-D889, 2001.

82. Schembri MA, Dalsgaard D and Klemm P: Capsule shields the function of short bacterial adhesins. J Bacteriol 186: 1249-1257, 2004.

83. Ring A, Weiser JN and Tuomanen EI: Pneumococcal trafficking across the blood-brain barrier. Molecular analysis of a novel bidirectional pathway. J Clin Invest 102: 347-360, 1998.

84. Talbot UM, Paton AW and Paton JC: Uptake of Streptococcus pneumoniae by respiratory epithelial cells. Infect Immun 64: 3772-3773, 1996.

85. Cundell DR, Weiser JN, Shen J, Young A and Tuomanen EI: Relationship between colonial morphology and adherence of Streptococcus pneumoniae. Infect Immun 63: 757-761, 1995.
86. Weiser JN, Austrian R, Sreenivasan PK and Masure HR: Phase variation in pneumococcal opacity: Relationship between colonial morphology and nasopharyngeal colonization. Infect Immun 62: 2582-2592, 1994.

87. Kim JO and Weiser JN: Association of intrastrain phase variation in quantity of capsular polysaccharide and teichoic acid with the virulence of Streptococcus pneumoniae. J Infect Dis 177: 368-377, 1998.

88. Schaffner TO, Hinds J, Gould KA, Wüthrich D, Bruggmann R, Küffer M, Mühlemann K, Hilty M and Hathaway LJ: A point mutation in cpsE renders Streptococcus pneumoniae nonencapsulated and enhances its growth, adherence and competence. BMC Microbiol 14: 210, 2014.

89. Okumura CY and Nizet V: Subterfuge and sabotage: Evasion of host innate defenses by invasive gram-positive bacterial pathogens. Annu Rev Microbiol 68: 439-458, 2014.

90. Reed JM, O'Callaghan RJ, Girgis DO, McCormick CC, Caballero AR and Marquart ME: Ocular virulence of capsule-deficient Streptococcus pneumoniae in a rabbit keratitis model. Invest Ophthalmol Vis Sci 46: 604-608, 2005.

91. Crum NF, Barrozo CP, Chapman FA, Ryan MA and Russell KL: An outbreak of conjunctivitis due to a novel unencapsulated Streptococcus pneumoniae among military trainees. Clin Infect Dis 39: 1148-1154, 2004.

92. Dixit C, Keller LE, Bradshaw JL, Robinson DA, Swiatlo E and McDaniel LS: Nonencapsulated Streptococcus pneumoniae as a cause of chronic adenoiditis. IDCases 4: 56-58, 2016. 